\title{
Peranan Career Anchor dalam Menciptakan Kepuasan Kerja Pegawai Dinas Kesehatan Kabupaten Sampang
}

\author{
Moch. Wispandono
}

Fakultas Ekonomi dan Bisnis

Universitas Trunojoyo Madura

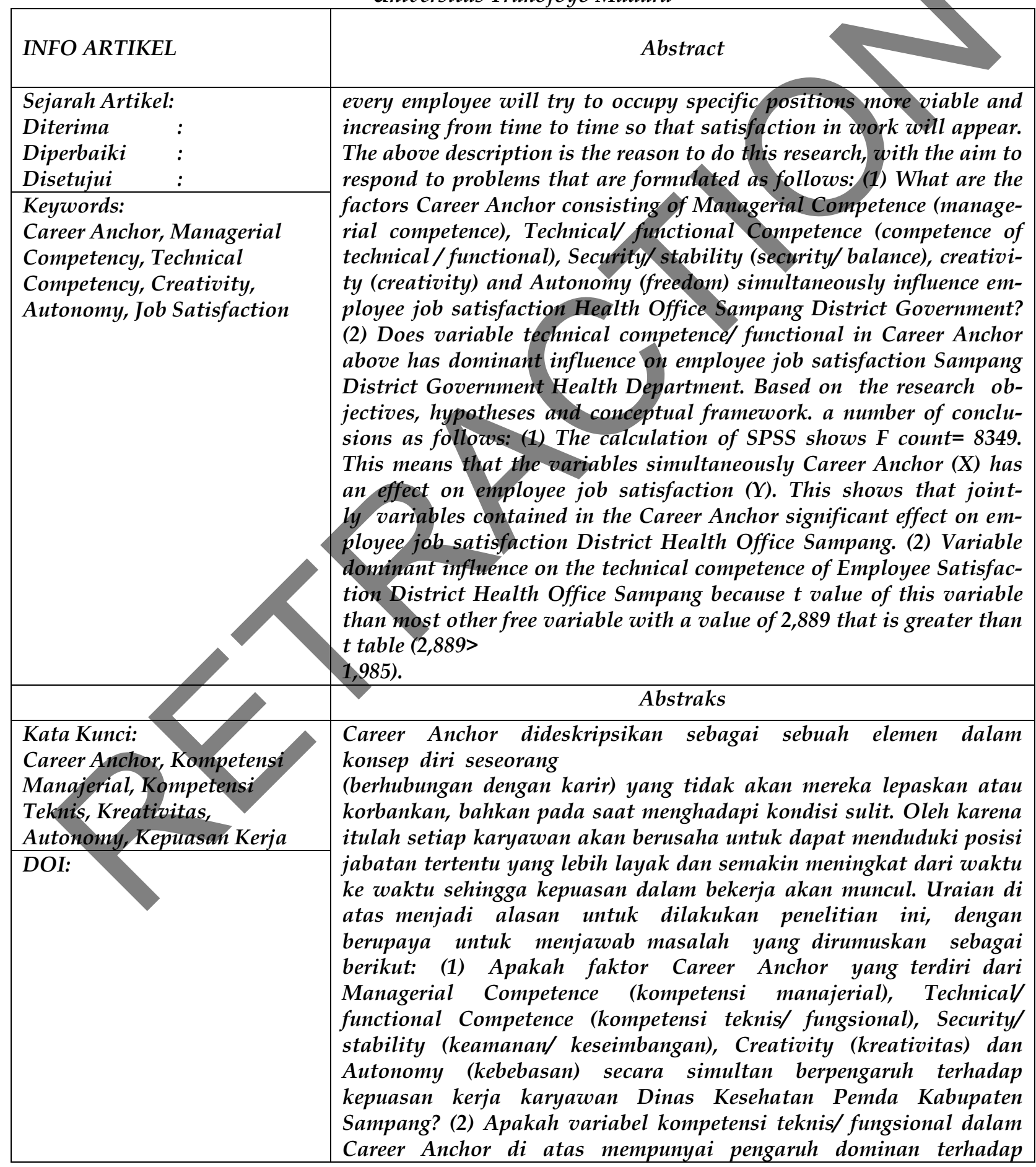




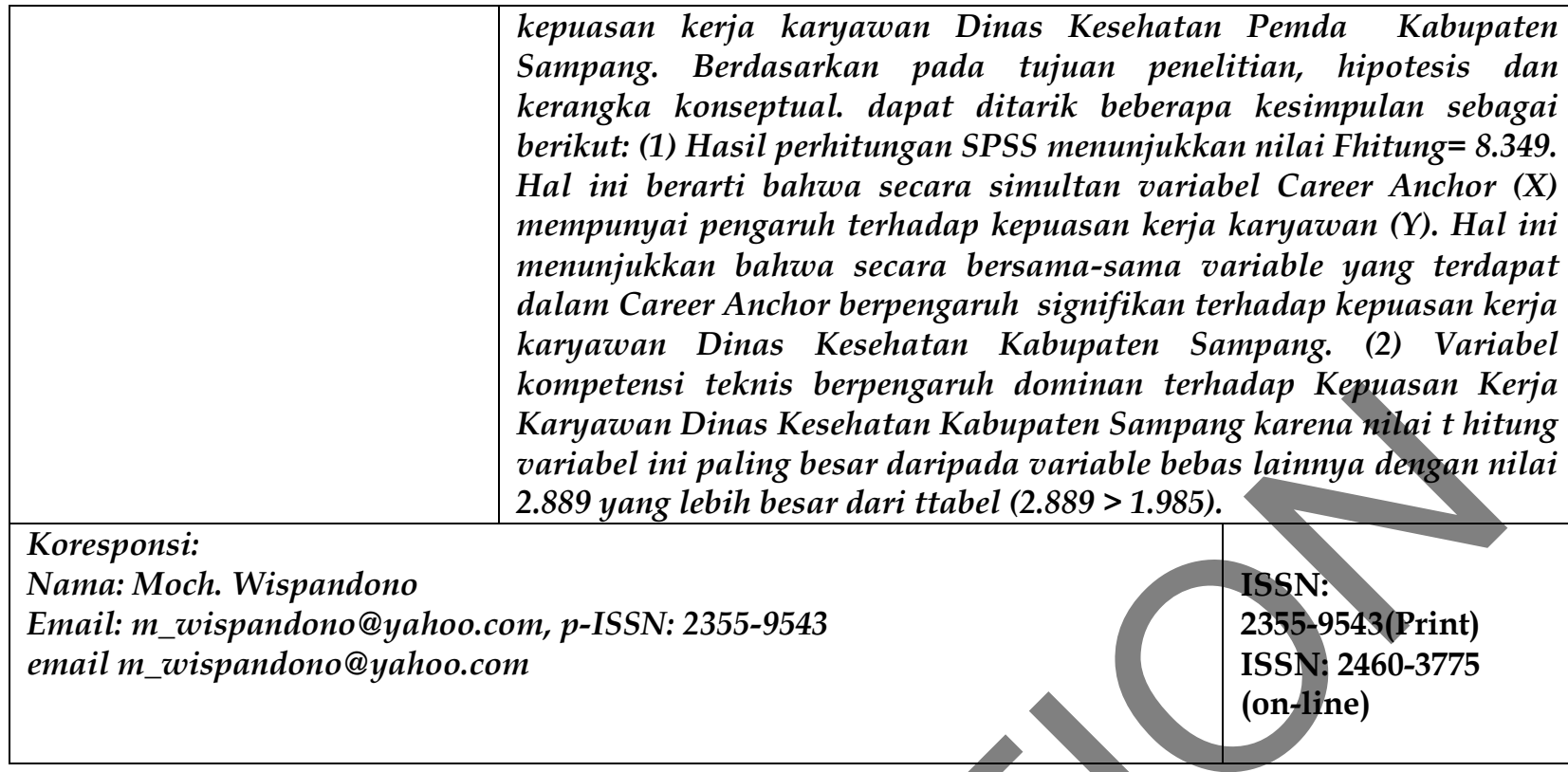

\section{PENDAHULUAN}

Setiap karyawan yang bekerja di dalam suatu organisasi telah memiliki rencana

untuk dalam jangka waktu tertentu karirya di tempat dia bekerja akan merangkak naik. Artinya, begitu dia bergabung di organisasi tersebut dia telah menyusun jalur karir yang akan ditempuh dan dilalui sampai jabatan terakhir yang akan didudukinya nanti menjelang pensiun. Jalur karir yang disusunnya ini tentu disesuaikan dengan tujuan yang akan dicapai karyawan tersebut dalam bekerja. Salah satu tujuan yang dicapainya adalah untuk mendapatkan kepuasan kerja. Untuk mencapai itu maka karyawan akan berusaha meningkatkan kompetensi yang disyaratkan dalam memangku jabatan barunya melalui Career Anchor.

Istilah Career Anchor pertama digunakan oleh Prof. Edgar H. Schein, berdasarkan penelitian jangka panjang dan studi yang mendalam yang dilakukannya dari tahun 1961-1973 terhadap 44 alumni program Master di Sloan School of Management. Career Anchor (Jangkar Karier) sendiri didefinisikan sebagai motif-motif yang mempengaruhi cara orang untuk memilih dan mempersiapkan kariernya. Menurut Schein Career Anchors is one of a number of well respected tools that can help you find the direction for your career development plans. (Career Anchor merupakan salah satu dari sejumlah piranti yang baik yang dapat membantu karyawan menemukan arah untuk rencana pengembangan karirnya.
Career Anchor juga dideskripsikan sebagai sebuah elemen dalam konsep diri seseorang yang tidak akan mereka lepaskan atau korbankan, bahkan pada saat menghadapi kondisi sulit (Career Anchors-Discovering your real values; Edgar $\mathrm{H}$. Schein, 1990). Berdasarkan hasil penelitiannya, Prof. Schein menyimpulkan bahwa ada

6 Jangkar Karier, yaitu:

(1). Kompetensi Manajerial. Tujuan karier dari para manajer adalah untuk mengembangkan kualitas interpersonal, analitikal, dan emosional. Orang yang menggunakan jangkar karier ini ingin mengelola orang, sebagai tujuan kariernya;

(2). Kompetensi Teknikal/ Fungsional. Jangkar untuk para teknisi/ spesialis adalah mengembangkan secara terus menerus bakat teknikal mereka. Orang-orang dengan jangkar ini tidak mencari posisi manajerial; (3). Keamanan. Orang-orang dengan jangkar karier ini ingin memperoleh situasi karier mereka stabil. Seringkali orang-orang ini mengikatkan dirinya dengan organisasi atau lokasi geografis tertentu. Orangorang dengan tipe jangkar ini akan mengalami stres bila berhadapan dengan situasi kerja atau bisnis yang tidak stabil/ bergejolak (Volatile); (4). Kreativitas. Orang-orang kreatif pada dasarnya mempunyai sifat enterpreneur pada dirinya. Mereka ingin membangun sesuatu yang seluruhnya merupakan hasil karyanya; (5). Otonomi dan kemandirian. Jangkar karier untuk orang yang mandiri adalah keinginan untuk memperoleh kebebasan dari batasan-batasan yang 
ada di dalam organisasi. Mereka memberikan nilai otonomi dan mereka ingin atasan dan juga pekerjaan sesuai dengan langkahnya; (6). Kompetensi Teknologikal. Orang-orang dengan jangkar ini sangat tertarik dengan teknologi dan mempunyai keinginan untuk bekerja dengan teknologi di mana pun hal itu dimungkinkan. Orang-orang ini seringkali mudah menerima perubahan. Karena itu mereka biasanya sangat mudah beradaptasi.

Berdasarkan uraian di atas, maka perumusan masalah yang akan diteliti adalah: (1) Apakah Career Anchor yang terdiri dari kompetensi manajerial, kompetensi teknis/ fungsional, Security/ stability (keamanan/ keseimbangan), Creativity (kreativitas) dan Autonomy (kebebasan) secara simultan mempunyai pengaruh terhadap kepuasan kerja karyawan Dinas Kesehatan Pemda Kabupaten Sampang? (2) Apakah variabel technical/ functional competence (kemampuan teknis/ fungsional) mempunyai pengaruh dominan terhadap kepuasan kerja karyawan Dinas Kesehatan Pemda Kabupaten Sampang mengingat di tempat penelitian ini seluruh karyawan dituntut untuk memiliki kemampuan teknis khususnya dalam melayani pasien.

Sejalan dengan rumusan masalah tersebut maka tujuan dalam penelitian ini adalah: (1) Untuk mengetahui dan menganalisis pengaruh faktorfaktor pengembangan karir yang terdiri dari Managerial Competence (kemampuan manajerial), Technical/functional Competence (kemampuan teknis/ fungsional), Security/stability (keamanan/ kebebasan), Creativity (kreativitas) dan Autonomy (kebebasan) secara simultan terhadap kepuasan kerja karyawan Dinas Kesehatan Pemda Kabupaten Sampang?, (2) Untuk mengetahui dan menganalisis apakah benar bahwa kemampuan teknis/ fungsional berpengaruh dominan terhadap kepuasan kerja karyawan Dinas Kesehatan Kabupaten Sampang?

Dessler (2005) dalam bukunya "Human Resource Management" menyatakan "career as the occupational positions a person has had over many year". Berdasarkan definisi ini maka karir dapat dikatakan sebagai suatu peluang seorang karyawan untuk menduduki posisi-posisi tertentu selama beberapa tahun. Sedangkan Kreitner \& Kinicki (1992: 299) menyatakan “A career is the pattern of work-related experiences that span the course of a person's life". Karir merupakan pola dari pengalaman-pengalaman yang berhubungan dengan pekerjaan sepanjang jalannya kehidupan seseorang. Selanjutnya Kreitner \& Kinicki menjelaskan dua hal yang mempengaruhi pola ini yaitu kejadian atau situasi obyektif dan interpretasi subjektif. Kejadian atau situasi obyektif terdiri dari rangkaian posisi kerja, tugas atau aktivitas kerja, dan keputusan yang berhubungan dengan pekerjaan. Sedangkan interpretasi subjektif merupakan penafsiran seseorang tentang kejadian-kejadian yang berhubungan dengan pekerjaan baik pada masa lalu, saat ini, ataupun masa mendatang seperti aspirasi kerja, pengharapan, nilai, kebutuhan dan perasaan tentang pengalaman kerja tertentu.

Simamora (1999:514) menyatakan bahwa: "perencanaan karir terdiri dari dua elemen utama, yaitu perencanaan karir organisasional (organizational career planning) dan perencanaan karir individual (individual career planning). Perencanaan karir organisasional mengintegrasikan kebutuhan sumber daya manusia dan sejumlah aktivitas karir, sedangkan prencanaan karir individual lebih terfokus pada ndividu yang meliputi kajian tentang keinginan, keahlian, dan hasrat seorang anggota. Dan yang lebih penting adalah sebagian latihan diagnostik dan prosedur untuk membantu individu yang bersangkutan untuk mengenal dirinya atau menentukan siapa yang sehubungan dengan potensi dan kemampuan".

Dalam kutipan Moh. As'ad yang terdapat pada buku "Psikologi Industri" (2000:104), Joseph Tiffin mendefinisikan kepuasan kerja adalah "sikap karyawan terhadap pekerjaan, situasi kerja, kerjasama diantara pimpinan dan sesama karyawan". Dan pendapat M.L Blum yang dikutip oleh Moh. As'ad dalam buku "Psikologi lndustri" (2000:102) mendefinisikan kepuasan kerja adalah "suatu sikap yang umum sebagai hasil dari berbagai sifat khusus individu terhadap faktor kerja, karakteristik individu dan hubungan sosial individu di luar pekerjaan itu sendiri".

Menurut Schein Career Anchor (Karir jangkar) adalah kombinasi dari elemen- elemen (karir) yang bisa menciptakan kepuasan kerja yang terdiri dari kompetensi, motif, dan nilai-nilai yang berkaitan dengan pilihan kerja profesional. Seringkali, orang memilih karir untuk semua alasan yang salah, dan menemukan respon mereka ke tempat kerja tidak sesuai dengan nilai-nilai sejati mereka. Situasi ini menyebabkan perasaan ketidak nyamanan dan ketidak puasan dan kehilangan produktivitas. Untuk membantu orang menghindari masalah ini, Career Anchor membantu orang menemukan nilai- 


\section{Peranan Career Anchor dalam Menciptakan Kepuasan,.. Moch. Wispandono}

nilai asli mereka dan menggunakannya untuk membuat pilihan karir yang lebih baik. Jangkar Karir-termasuk bakat, motif, nilai dan sikap yang bisa memberikan stabilitas dan arah untuk karir seseorang. Sebuah jangkar karir adalah salah satu unsur dalam konsep diri seseorang yang menyatakan bahwa seseorang tidak akan menyerah, bahkan dalam menghadapi pilihan yang sulit.

Berdasarkan tinjauan teoritis di atas maka dalam penelitian ini terdapat hipotesis kerja yang peneliti dapatkan dalam kajian teori. Hipotesis yang diajukan dalam penelitian ini adalah mengacu pada rumusan masalah yang menyangkut hubungan kausalitas antara variabel bebas dan variabel terikat. Di samping itu juga didasarkan atas deskripsi teoritik dan kerangka konseptual. Oleh karena itu hipotesis kerja yang diajukan dalam penelitian ini adalah: (1) diduga bahwa variable-variabel Career Anchor yang meliputi Managerial Competence (X1), Technical/ functional Competence (X2), Security/ stability (X3), Creativity (X4) dan Autonomy (X5) secara simultan berpengaruh signifikan terhadap kepuasan kerja karyawan Dinas Kesehatan Pemda Kabupaten Sampang. (2) Diduga bahwa variable kompetensi teknis/ fungsional berpengaruh dominan terhadap kepuasan kerja karyawan Dinas Kesehatan Pemda Kabupaten Sampang.

\section{METODE}

Metode penelitian memegang peranan penting dalam kaitannya dengan penelitian karena pada hakekatnya penelitian merupakan suatu penyelidikan yang sistematis untuk meningkatkan sejumlah pengetahuan, juga merupakan suatu usaha yang sistematis dan terorganisasi untuk menyelidiki masalah tertentu yang memerlukan jawaban dan hasilnya dapat dipertanggungjawabkan kebenarannya secara ilmiah.

Metode yang digunakan dalam penelitian ini adalah metode penelitian kuantitatif karena dalam penelitian ini berupaya untuk melakukan pengukuran data kuantitatif dan pengujian hipotesis melalui perhitungan ilmiah analisis statistik dari populasi atau sampel karyawan yang diminta menjawab atas sejumlah pertanyaan tentang survei untuk menentukan frekuensi dan persentase tanggapan mereka.

Populasi dalam penelitian ini adalah seluruh karyawan Dinas Kesehatan Pemda Kabupaten Sampang yang berstatus PNS yaitu sebanyak 97 karyawan. Semua karyawan Dinas Kesehatan Pemda Kabupaten Sampang yang tersebar di berbagai bidang (seperti yang nampak dalam struktur organisasi di halaman berikut) menjadi responden. Hal ini sesuai dengan pendapat Arikunto (2006:112) yang mengemukakan bahwa apabila subyek kurang dari 100, maka lebih baik diambil semua, sehingga penelitiannya merupakan penelitian populasi. Penelitian ini menggunakan seluruh populasi untuk dijadikan responden tanpa ada sampel penelitian. Dengan demikian penelitian ini adalah penelitian populasiatau sensus

Penelitian ini memiliki variabel inti, yaitu variabel bebas $(X)$ dan variabel terikat (Y). Variabel bebas (Independent Variabel) dalam penelitian ini adalah Career Anchor $(\mathrm{X})$, yang terdiri dari manajerial competance (kemampuan manajerial) (X1), technical/ functional competance (kemampuan teknis/ fungsional) (X2), security/ stability (keamananX keseimbangan) (X3), creatifity (kreatifitas) (X4), autonomy (kebebasan) (X5). Sedangkan variabel terikat (Dependent Variabel) dari penelitian ini adalah kepuasan kerja karyawan Dinas Kesehatan Pemda Kabupaten Sampang khususnya yang sudah berstatus PNS (Y). Penelitian ini menggunakan variable-variabel yang terdapat dalam Career Anchor (menurut Dessler dalam Benyamin Molan, 1999:328), antara lain: (1) Manajerial Competance (X1): Managerial Competence merupakan kemampuan seorang karyawan untuk menjadi pengelola atau manajer yang didukung oleh keahlian dan nilai yang dibutuhkan untuk meningkat ke posisi manajerial tertentu. (2) Technical/functional Competance (X2): Technical FunctionalCompetence merupakan kemampuan teknis seorang karyawan dalam melaksanakan suatu pekerjaan yang dikembangkan secara berkesinambungan. (3) Security/ stability (X3): Security merupakan kebutuhan seseorang karyawan akan stabilitas karir dan penghasilannya, baik pada saat ini maupun masa mendatang. (4) Creatifity (X4): Creativity merupakan proses berfikir seorang karyawan dalam menciptakan ide atau konsep yang baru, penciptaan, berguna dan memuaskan bagi karyawan tersebut maupun perusahaan. (5) Autonomy (X5): Autonomy dapat disimpulkan bahwa merupakan keinginan seorang karyawan untuk tetap mempertahankan kebebasan dan otonomi dalam melaksanakan tugas sesuai dengan karir yang dijabatnya. Kepuasan Kerja (Y): emosional yang menyenangkan dengan mana para karyawan memandang pekerjaan mereka. 


\section{Jurnal Studi Manajemen dan Bisnis}

Vol. 5 (2) 2018

\section{Teknik Analisis Data}

\section{Uji Validitas}

Data yang digunakan merupakan hasil skor dari kuesioner yang disebarkan pada responden, data tersebut kemudian diuji validitasnya. Sebuah pertanyaan/ pernyataan dikatakan valid jika pertanyaan tersebut dapat mengukur apa yang ingin diukur. Pengujian terhadap validitas pertanyaan dilakukan dengan menggunakan uji korelasi produk moment person. Untuk menguji apakah korelasi tersebut signifikan atau tidak, maka hasil uji $r$ hitung dapat dibandingkan dengan $\mathrm{r}$ tabel dengan taraf signifikansi 95\%.

\section{Uji Reliabilitas}

Uji reliabilitas dilakukan untuk mengetahui sejauh mana hasil pegukuran

tersebut dapat diandalkan. Pada penelitian ini, uji reliabilitas alat ukur yang akan digunakan adalah Cronbach Alpha dengan tujuan untuk mengetahui apakah pengukuran yang kita buat itu reliabel atau tidak. Menurut Ghozali (2003:41) suatu kuesioner dikatakan reliabel atau handal jika jawaban seseorang terhadap pernyataan adalah konsisten atau stabil dari waktu ke waktu. Dengan ketentuan jika nilai dari Cronbach Alpha mendekati 1,00 atau berada pada kisaran antara 0,65-1,00 atau dapat diartikan suatu konstruk atau variabel tersebut memberikan nilai Cronbach Alpha $>0,60$.

Jika konstruk atau variabel tersebut setelah diukur memberikan nilai Cronbach Alpha > 0,60 maka pengukuran instrumen (angket) yang kita gunakan itu reliabel, atau jawaban responden yang memiliki karakteristik sama dalam menjawab angket akan cenderung memberikan jawaban yang sama walaupun diberikan kepada responden lain dalam bentuk pertanyaan yang berbeda.

Proses dari uji validitas dan reliabilitas kuisioner yang akan peneliti lakukan adalah pertama, instrumen penelitian (angket/ kuesioner) yang telah disusun, dikonsultasikan kepada orangorang yang berkompeten di bidangnya. langkah kedua adalah melakukan pengujian angket terlebih dahulu untuk menilai validitasnya secara empirik, dalam proses ini peneliti akan melakukan uji validitas dan reliabilitas setiap butir instrumen, maka untuk mengawalinya dilakukan uji coba angket awal, dengan sasaran 97 karyawan Dinas Kesehatan Pemda Kabupaten Sampang yang berstatus PNS. Kemudian langkah ketiga, data yang diperoleh dari responden, dilakukan analisis dengan mengkorelasikan skor setiap butir-butir soal. Setelah itu peneliti akan

mengetahui tingkat validitas angket yang menunjukkan sejauh mana suatu alat pengukur itu mengukur apa yang ingin diukur sekaligus diketahui tingkat reliabilitasnya yang menunjukkan sejauh mana suatu hasil pengukuran relatif konsisten apabila pengukuran

terhadap aspek yang sama pada alat ukur yang sama atau disebut juga Internal

Constitency Reliability. Jenis validitas dalam penelitian ini adalah validitas konstruk. Validitas konstruk ini lebih terarah pada pernyataan mengenai apa yang sebenarnya diukur oleh alat pengukur. Dengan kata lain, validitas konstruk berkaitan dengan pengertian, kegunaan atau manfaat dan asosiasi variabel-variabel terukur atau teramati tersebut dengan sebuah variabel tidak terukur. Pengukuran tersebut dapat dilihat pada Corrected Item-Total Correlation tampilan pada hasil SPSS uji reliabilitas yang peneliti olah.Corrected Item-Total Correlation adalah korelasi antara item bersangkutan dengan seluruh item sisa lainnya. Jika nilai Corrected Item-Total Correlation lebih besar maka pernyataan tersebut dapat dinyatakan valid dengan syarat menggunakan taraf signifikansi angka kritik nilai r, yaitu N-2 (melihat lampiran tabel angka kritik nilai r).

Seteleh mengumpulkan data primer yang dihasilkan dari membagikan kuesioner kepada responden yaitu karyawan Dinas Kesehatan Pemda Kabupaten Sampang melakukan analisis dengan model persamaan regresi linier berganda (multiple linier regression analysis) untuk meregresikan secara simultan antara variabel bebas (independent variable) dan variabel terikat (dependent variable).

Menurut Algifari (2000:61) model regresi linier berganda dikembangkan untuk mengestimasi nilai variabel dependen $(Y)$ dengan menggunakan lebih dari satu variabel independen $(X)$ sehingga persamaan regresi berganda dapat ditulis sebagai berikut:

$Y=a+b 1 \times 1+b 2 \times 2+b 3 \times 3+b 4 \times 4+b 5 \times 5+c$

Keterangan:

$\mathrm{Y} \quad=$ Kepuasan Kerja

$\mathrm{A}=$ konstanta

$\mathrm{X} 1 \quad=$ managerial competence 


\section{Peranan Career Anchor dalam Menciptakan Kepuasan,..}

Moch. Wispandono

$\mathrm{X} 2=$ technical competence

$\mathrm{X} 3=$ security

X4 = creativity

X5 =autonomy

$\mathrm{b} 1 \ldots . . \mathrm{b} 2=$ Koefisien regresi untuk masingmasing variabel.

$\mathrm{C}=$ Variabel pengganggu/ error term

\section{Koefisien Determinasi Berganda (R2)}

Koefisien determinasi berganda digunakan untuk menjelaskan kemampuan model persamaan regresi berganda dalam menjelaskan pengaruh perubahan variabel dependen (variabel terikat) terhadap variabel independen (variabel bebas). Menurut Algifari (2002:46) bahwa koefisien determinasi (R2) adalah satu dikurangi rasio, antara besarnya deviasi nilai $\mathrm{Y}$ observasi dari garis regresi dengan besarnya deviasi nilai $\mathrm{Y}$ observasi dari rata-ratanya. Atau secara matematis dapat ditulis sebagai berikut:

$$
\mathbf{R}^{2}=\overline{\sum(Y-Y)^{2}}
$$

Bila nilai R2 semakin mendekati 1 atau $100 \%$, berarti semakin baik model regresinya dalam menjelaskan variabilitas variabel terikat.

\section{Koefisien Korelasi Berganda (R)}

Koefisien korelasi berganda digunakan untuk menunjukkan kuat atau lemahnya hubungan antara variabel terikat dan variabel bebas. Koefisien korelasi berganda (R) dapat diukur dengan rumus<smiles>[R]#C[W]</smiles>

\section{PEMBAHASAN}

Selayang Pandang Dinas Kesehatan Kabupaten Sampang

\section{VISI}

“Terwujudnya Dinas Kesehatan sebagai pengendali dan penyelenggara pembangunan kesehatan, yang efektif dan efisien, menuju masyarakat Sampang yang sehat, mandiri, berkeadilan, dan berdaya saing".

\section{MISI}

1. Meningkatkan partisipasi dan keberdayaan masyarakat dalam pembangunan

kesehatan.

2. Mewujudkan ketersediaan dan terjaminnya akses pelayanan kesehatan yang bermutu dan komprehensif.

3. Meningkatkan upaya penyehatan lingkungan, pengendalian penyakit, pencegahan dan penanggulangan permasalahan kesehatan.

4. Mewujudkan ketersediaan SDM, Obat, Sarana dan Prasarana Kesehatan, Pembiayaan

Kesehatan, SIK, dan SIM Kesehatan.

5. Mewujudkan manajemen yang bermutu, efektif dan efisien dalam pengelolaan kesehatan wilayah melalui pengendalian dan pengawasan.

Struktur Organisasi

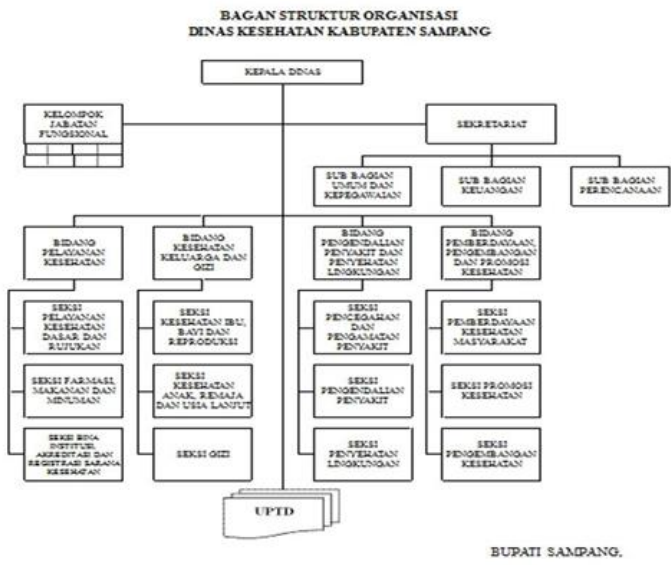

\section{Deskripsi Responden}

Dari kuesioner yang telah diisi oleh responden didapat data identitas responden.

Penyajian data mengenai identitas responden untuk memberikan gambaran tentang keadaan diri dari pada responden.

\section{Umur Responden}

Umur dalam keterkaitannya dengan perilaku individu di lokasi kerja biasanya

adalah sebagai gambaran akan pengalaman dan tanggung jawab individu. Tabulasi umur responden dapat dilihat sebagai berikut:

Tabel 1. Umur Responden

\begin{tabular}{|c|c|c|}
\hline Umur (tahun) & $\begin{array}{c}\text { Jumlah } \\
\text { Responden }\end{array}$ & Persentase \\
\hline $\mathbf{1 9}-\mathbf{3 2}$ & $\mathbf{1 7}$ & $\mathbf{1 7 , 5 3}$ \\
$\mathbf{3 3}-\mathbf{4 6}$ & $\mathbf{5 2}$ & $\mathbf{5 3 , 6 0}$ \\
$\mathbf{4 7}-\mathbf{6 0}$ & $\mathbf{2 8}$ & $\mathbf{2 8 , 8 7}$ \\
& & \\
& & \\
\hline Total & $\mathbf{9 7}$ & $\mathbf{1 0 0 . 0 0}$ \\
\hline
\end{tabular}

Sumber: Data primer yang diolah, 2015.

Berdasarkan tabel 1 dapat diketahui bahwa 


\section{Jurnal Studi Manajemen dan Bisnis}

Vol. 5 (2) 2018

untuk umur responden yang terbanyak adalah umur kurang atau sama dengan 32-45 tahun yaitu sebanyak 52 orang atau 53,60\%, diikuti dengan usia responden 46-59 tahun sebanyak 28 orang atau 28,87 \%. Hal ini menunjukkan bahwa karyawan Dinas Kesehatan Pemda Kabupaten Sampang sebagian besar masih berusia muda dan pada umur yang sangat produktif. Hal ini menunjukkan bahwa pada usia yang masih relatif muda, semangat kerja yang dimiliki masih relatif tinggi.

\section{Jenis Kelamin Responden}

Jenis kelamin secara umum dapat memberikan perbedaan pada perilaku

seseorang. Dalam suatu bidang kerja jenis kelamin seringkali dapat menjadi pembeda aktivitas yang dilakukan oleh individu Penyajian data responden berdasarkan jenis kelamin adalah sebagai berikut ini:

Tabel 2. Jenis Kelamin Responden berpendidikan S1 yaitu sebanyak 35 orang atau $36,08 \%$ dari jumlah responden. Hal ini menunjukkan bahwa karyawan Dinas Kesehatan Pemda Kabupaten Sampang sebagian besar memiliki pendidikan tinggi. Hal ini disebabkan karena jumlah dokter lebih banyak dari pada petugas administrasi maupun perawat.

\section{Deskripsi Variabel Penelitian}

Berdasarkan hasil penelitian yang telah dilakukan terhadap 97 responden

melalui penyebaran kuesioner. Untuk mendapatkan kecenderungan jawaban responden terhadap jawaban masing-masing variabel akan didasarkan pada rentang skor jawaban sebagaimana pada lampiran.

Deskripsi Variabel Career Anchor

Variabel Career Anchor pada penelitian ini diukur melalui 5 buah indikator.

Hasil tanggapan terhadap variabel Career Anchor dapat dijelaskan pada Tabel 4 berikut ini:

Tabel 4. Tanggapan Responden mengenai Career

\begin{tabular}{|c|c|c|}
\hline Jenis Kelamin & Jumlah Responden & Persentase \\
\hline Laki-laki & $\mathbf{5 8}$ & $\mathbf{5 9 , 7 9}$ \\
Perempuan & $\mathbf{3 9}$ & $\mathbf{4 0 , 2 1}$ \\
\hline Total & $\mathbf{9 7}$ & $\mathbf{1 0 0 , 0 0}$ \\
\hline
\end{tabular}

Berdasarkan tabel 2 dapat diketahui bahwa responden terbanyak adalah laki-laki yaitu sebanyak 58 orang $(59,79 \%)$ dibanding perempuan yang hanya 39 orang $(40,21 \%)$. Ha ini menunjukkan bahwa jenis kelamin laki-laki sebagai proporsi yang lebih besar dibanding karyawan perempuan yang bekerja pada Dinas Kesehatan Pemda Kabupaten Sampang. Hal ini disebabkan karena untuk pekerjaan yang memerlukan tenaga fisik, laki-laki secara umum dipandang lebih baik dibanding prempuan.

\section{Pendidikan Responden}

Pendidikan seringkali dipandang sebagai satu kondisi yang mencerminkan kemampuan seseorang. Penyajian data responden berdasarkan pendidikan adalah sebagaimana terlihat pada Tabel 4.3 berikut ini:

\section{Tabel 3. Pendidikan Responden}

\begin{tabular}{|l|c|c|}
\hline Pendidikan & Jumlah Responden & Persentase \\
\hline SLTA & 12 & 12,37 \\
D3 & 32 & 32,99 \\
S1 & 35 & 36,08 \\
S2 & 18 & 18,56 \\
& & \\
\hline Jumlah & 97 & 100,00 \\
\hline
\end{tabular}

Sumber: Data primer yang diolah, 2015

Berdasarkan Tabel 3 menunjukkan data bahwa jumlah responden yang terbanyak adalah dari kelompok responden yang

\begin{tabular}{|l|l|l|l|l|l|l|l|}
\hline \multirow{2}{*}{ No } & Pernyataan & \multicolumn{9}{|l|}{ Skor } & \multicolumn{4}{|l|}{ Jumlah } \\
\cline { 3 - 7 } & & SS & S & N & TS & STS & \\
\hline 1 & $\mathrm{X}_{1}$ & 35 & 47 & 15 & 0 & 0 & 97 \\
\cline { 3 - 7 } & & $36 \%$ & $48 \%$ & $16 \%$ & $0 \%$ & $0 \%$ & $100 \%$ \\
\hline 2 & $\mathrm{X}_{2}$ & 28 & 58 & 11 & 0 & 0 & 97 \\
\hline
\end{tabular}

\begin{tabular}{|c|c|c|c|c|c|c|c|}
\hline \multirow[t]{3}{*}{ No } & \multirow[t]{3}{*}{ Pernyataan } & \multicolumn{5}{|l|}{ Skor } & \multirow[t]{2}{*}{ Jumlah } \\
\hline & & SS & $\mathbf{S}$ & $\mathrm{N}$ & TS & STS & \\
\hline & & $29 \%$ & $64 \%$ & $18 \%$ & $0 \%$ & $0 \%$ & $100 \%$ \\
\hline \multirow[t]{2}{*}{3} & \multirow[t]{2}{*}{$\mathrm{X}_{3}$} & 20 & 62 & 15 & 0 & 0 & 97 \\
\hline & & $21 \%$ & $64 \%$ & $15 \%$ & $0 \%$ & $0 \%$ & $100 \%$ \\
\hline \multirow[t]{2}{*}{4} & \multirow[t]{2}{*}{$\mathrm{X}_{4}$} & 79 & 0 & 18 & 0 & 0 & 97 \\
\hline & & $81 \%$ & $0 \%$ & $19 \%$ & $0 \%$ & $0 \%$ & $100 \%$ \\
\hline \multirow[t]{4}{*}{5} & \multirow[t]{2}{*}{$\mathrm{X}_{5}$} & 20 & 64 & 13 & 0 & 0 & 97 \\
\hline & & $21 \%$ & $66 \%$ & $13 \%$ & $0 \%$ & $0 \%$ & $100 \%$ \\
\hline & Jumlah & 182 & 231 & 72 & 0 & 0 & 485 \\
\hline & & $37 \%$ & $48 \%$ & $15 \%$ & $0 \%$ & $0 \%$ & $100 \%$ \\
\hline
\end{tabular}

Sumber: Data primer yang diolah, 2015

Tanggapan respoden sebagaimana pada tabel 4 menunjukkan bahwa sebagian besar responden memberikan tanggapan setuju terhadap variabel Career Anchor. Hal ini menunjukkan adanya penilaian terhadap Career Anchor yang tinggi yang dimiliki karyawan.

Berdasarkan pertanyaan pertama menunjukkan bahwa para karyawan merasa cukup mempunyai kelayakan dalam Managerial Competence. Hasil ini ditunjukkan oleh $36 \%$ jawaban sangat setuju, 48 $\%$ jawaban setuju dan $16 \%$ jawaban netral.

Berdasarkan pertanyaan kedua menurut responden menunjukkan bahwa mereka sudah bekerja berdasarkan standar yang telah ditetapkan. Hasil ini ditunjukkan oleh

$29 \%$ jawaban sangat setuju, $64 \%$ jawaban setuju 


\section{Peranan Career Anchor dalam Menciptakan Kepuasan,.. Moch. Wispandono}

dan $18 \%$ jawaban netral.

Pada pertanyaan ketiga menunjukkan bahwa karyawan merasakan bahwa mereka membutuhkan keamanan dalam bekerja. Hasil ini ditunjukkan oleh $21 \%$ jawaban sangat setuju $64 \%$ jawaban setuju dan $15 \%$ jawaban netral.

Berdasarkan item pertanyaan keempat menurut karyawan bahwa mereka cukup mendapat motivasi untuk menciptakan ide atau konsep baru atas pekerjaan yang dilakukan. Hasil ini ditunjukkan oleh $81 \%$ jawaban sangat setuju dan $19 \%$ jawaban netral.

Berdasarkan item pertanyaan kelima menurut karyawan bahwa mereka cukup mendapatkan kebebasan dalam melaksanakan tugas. Hasil ini ditunjukkan oleh $21 \%$ jawaban sangat setuju, $66 \%$ jawaban setuju dan $13 \%$ jawaban netral.

Semua item pertanyaan untuk variabel Career Anchor (X) mempunyai nilai korelasi lebih besar dari 0.3 dengan demikian berarti bahwa item pertanyaan untuk variabel Career Anchor $(X)$ valid untuk pengujian selanjutnya.

Hasil uji reliabilitas tersebut menunjukkan bahwa semua variabel mempunyai koefisien Alpha yang cukup besar yaitu diatas 0,60 sehingga dapat dikatakan semua konsep pengukur masing-masing variabel dari kuesioner adalah reliabel sehingga untuk selanjutnya item-item pada masing-masing konsep variabel tersebut layak digunakan sebaga alat ukur.

Deskripsi Variabel Kepuasan Kerja Karyawan Variabel kepuasan kerja karyawan pada penelitian ini diukur melalui 6 buah

indikator. Hasil tanggapan terhadap kepuasan kerja karyawan dapat dijelaskan pada tabel 5 berikut ini:

Tabel 5. Tanggapan Responden mengenai Kepuasan Kerja Karyawan

\begin{tabular}{|c|c|c|c|c|c|c|c|}
\hline \multirow[t]{2}{*}{ No } & \multirow[t]{2}{*}{ Pernyataan } & \multicolumn{5}{|l|}{ Skor } & \multirow[t]{2}{*}{ Jml } \\
\hline & & SS & $\mathbf{S}$ & $\mathbf{N}$ & TS & STS & \\
\hline \multirow[t]{2}{*}{1} & \multirow[t]{2}{*}{$\mathrm{Y}_{1}$} & 54 & 42 & 1 & 0 & 0 & 97 \\
\hline & & $56 \%$ & $43 \%$ & $1 \%$ & $0 \%$ & $0 \%$ & $100 \%$ \\
\hline \multirow[t]{2}{*}{2} & \multirow[t]{2}{*}{$\mathrm{Y}_{2}$} & 49 & 37 & 11 & 0 & 0 & 97 \\
\hline & & $51 \%$ & $38 \%$ & $11 \%$ & $0 \%$ & $0 \%$ & $100 \%$ \\
\hline \multirow[t]{2}{*}{3} & \multirow[t]{2}{*}{$\mathrm{Y}_{3}$} & 51 & 38 & 8 & 0 & 0 & 97 \\
\hline & & $53 \%$ & $39 \%$ & $8 \%$ & $0 \%$ & $0 \%$ & $100 \%$ \\
\hline \multirow[t]{2}{*}{4} & \multirow[t]{2}{*}{$\mathrm{Y}_{4}$} & 53 & 39 & 5 & 0 & 0 & 97 \\
\hline & & $55 \%$ & $40 \%$ & $5 \%$ & $0 \%$ & $0 \%$ & $100 \%$ \\
\hline \multirow[t]{2}{*}{5} & \multirow[t]{2}{*}{$\mathrm{Y}_{5}$} & 11 & 32 & 39 & 15 & 0 & 97 \\
\hline & & $11 \%$ & $33 \%$ & $40 \%$ & $16 \%$ & $0 \%$ & $100 \%$ \\
\hline \multirow[t]{4}{*}{6} & \multirow[t]{2}{*}{$\mathrm{Y}_{6}$} & 7 & 32 & 43 & 15 & 0 & 97 \\
\hline & & $7 \%$ & $33 \%$ & $44 \%$ & $16 \%$ & $0 \%$ & $100 \%$ \\
\hline & \multirow[t]{2}{*}{ Jumlah } & 225 & 220 & 107 & 30 & 0 & 582 \\
\hline & & $39 \%$ & $38 \%$ & $18 \%$ & $5 \%$ & $0 \%$ & $100.0 \%$ \\
\hline
\end{tabular}

Sumber: Data primer yang diolah, 2015
Tanggapan respoden sebagaimana pada tabel 5 menunjukkan bahwa sebagian besar responden memberikan tanggapan sangat setuju terhadap item kepuasan kerja karyawan. Hal ini menunjukkan adanya penilaian terhadap kepuasan kerja yang tinggi yang dimiliki karyawan pada Dinas Kesehatan Pemda Kabupaten Sampang.

Berdasarkan item pertama menunjukkan bahwa secara karyawan merasa puas dengan pekerjaannya dan bebas mengarahkan ketrampilan dan kemampuannya dalam bekerja. Hasil ini ditunjukkan oleh $56 \%$ jawaban sangat setuju, $43 \%$ jawaban setuju dan $1 \%$ jawaban netral.

Berdasarkan item kedua menunjukkan bahwa gaji yang mereka terima sudah sesuai dengan yang mereka harapkan. Hasil ini ditunjukkan oleh $51 \%$ jawaban sangat setuju, $38 \%$ jawaban setuju dan 11 $\%$ jawaban netral.

Berdasarkan item ketiga menunjukkan bahwa sebagian besar responden menyatakan sudah puas dengan kebijakan promosi yang diterapkan saat ini. Hasil ini ditunjukkan oleh $53 \%$ jawaban sangat setuju, $39 \%$ jawaban setuju dan $8 \%$ jawaban netral.

Berdasarkan item keempat menunjukkan bahwa sebagian besar karyawan menyatakan cukup nyaman dengan pengawasan yang diberikan oleh instansi. Hasil ini ditunjukkan oleh $7 \%$ jawaban sangat setuju, $33 \%$ jawaban setuju, $44 \%$ jawaban netral dan $16 \%$ jawaban tidak setuju.

Berdasarkan item kelima menunjukkan bahwa sebagian besar karyawan menyatakan dapat bekerja sama dengan baik dengan sesama rekan pekerja. Hasil ini ditunjukkan oleh $11 \%$ jawaban sangat setuju, $33 \%$ jawaban setuju, $40 \%$ jawaban netral dan $16 \%$ jawaban tidak setuju.

Berdasarkan item keenam menunjukkan bahwa sebagian besar karyawan menyatakan cukup nyaman dengan kondisi lingkungan kerjanya. Hasil ini ditunjukkan oleh $7 \%$ jawaban sangat setuju, 33 $\%$ jawaban setuju, $44 \%$ jawaban netral dan $16 \%$ jawaban tidak setuju.

Berdasarkan hasil pengujian secara statistik dapat terlihat dengan jelas bahwa secara parsial (individu) semua variabel bebas berpengaruh terhadap variabel terikat. Pengaruh yang diberikan ketiga variabel bebas tersebut bersifat positif artinya semakin tinggi Career Anchor (X) maka mengakibatkan semakin tinggi pula kepuasan kerja 


\section{Jurnal Studi Manajemen dan Bisnis \\ Vol. 5 (2) 2018}

karyawan yang dihasilkan. Hasil tersebut sesuai dengan hipotesis yang diajukan. Hasil penelitian ini juga sesuai dengan hasil penelitian sebelumnya. Penjelasan dari masing- masing pengaruh variabel dijelaskan sebagai berikut:

Pengaruh Career Anchor terhadap Kepuasan Kerja Karyawan

Hasil pengujian hipotesis (H1) telah membuktikan terdapat pengaruh antara

Career Anchor terhadap kepuasan kerja karyawan. Melalui hasil perhitungan yang telah dilakukan diperoleh nilai t hitung sebesar 2.889 dengan taraf signifikansi hasil sebesar 0,000 tersebut lebih kecil dari 0,05, dengan demikian Ha diterima dan Ho ditolak. Pengujian ini secara statistik membuktikan bahwa Career Anchor berpengaruh positif terhadap kepuasan kerja karyawan. Artinya bahwa ada pengaruh antara variabel Career Anchor terhadap kepuasan kerja karyawan Dinas Kesehatan Pemda Kabupaten Sampang. Hasil ini mendukung penelitian sebelumnya oleh (Suranta, 2002) yang menguji pengaruh Career Anchor terhadap kepuasan kerja karyawan dengan hasil analisis yaitu Career Anchor mempunyai pengaruh positif dan signifikan terhadap kepuasan kerja karyawan.

\section{SIMPULAN}

Berdasarkan pada tujuan penelitian, hipotesis dan kerangka konseptual. dapat

ditarik beberapa kesimpulan sebagai berikut: (1) Hasil perhitungan SPSS menunjukkan nilai Fhitung= 8.349. Hal ini berarti bahwa secara simultan variabel Career Anchor (X) mempunyai pengaruh terhadap kepuasan kerja karyawan $(Y)$. Hal ini menunjukkan bahwa faktor-faktor pengembangan karir yang terdiri dari managerial competence, technical functional competence, security, creativity, dan autonomy and independence secara bersama-sama mempunyai pengaruh yang signifikan terhadap kepuasan kerja karyawan Dinas Kesehatan Kabupaten Sampang. (2) Variabel Career Anchor (X) yang berupa kemampuan teknis/ fungsional secara parsial berpengaruh dominan dan signifikan terhadap Kepuasan Kerja Karyawan Dinas Kesehatan Kabupaten Sampang karena $t$ hitung dari kemampuan teknis ini terbesar dan lebih besar dari ttabel $(2.889>$ 1.985).

\section{DAFTAR PUSTAKA}

Algifari. 2000. Analisis Regresi Teori, Kasus, dan Solusi. Edisi Kedua. BPFE:

Yogyakarta.

Arikunto, Suharsimi.1996. Prosedur Penelitian. Jakarta : Rineka Cipta.

Amold, Hugh J and Daniel C. Feldman. 1986. Organizational Behaviour. Intemational

Edition. Singapore: McGraw-Hill.

Davis, Keith dan John W. Newstrom. 1990. Human Behaviour At Work Organizational

Behaviour. Eighth Edition. McGraw-Hill Intemational.

Dessler, Gary. 1986. Manajemen Personalia: Tehnik dan Konsep Modern. Edisi 3.

Terjemahan Jakarta: Penerbit Erlangga.

Dessler, Gary. 1997. Manajemen Sumber Daya Manusia. Edisi Bahasa Indonesia. Jilid

2. Jakarta: PT Prenhallindo.

Dubrin, Andrew J, R. Duane Ireland and J. Clifton Williams. 1989. Management and

Organization. Cincinnati: South-Westem Publishing.

Dubrin, Andrew J. 1988. Human Relations: A Job Oriented Approach. Fourth Edition.

Englewood Clifft, New Jersey: Prentise Hall International.

Flippo, Edwin B. 1992. Manajemen Personalia. Jilid 1. Terjemahan. Jakarta: Penerbit

Erlangga.

Ghozali, Imam. 2001. Aplikasi Analisis multivariate dengan Program SPSS. Edisi

Kedua. Semarang: Badan Penerbit Universitas Diponegoro.

Gibson, James L, John 1 Z1 Ivancevich and James H Donnely, Jr. 1994. Organisasi dan

Manajemen. Edisi 4. Terjemahan. Jakarta: Penerbit Erlangga. Green, Graham. 2003. The Caree Change Handbook, howtobooks.

Handoko, T. Hani. 1998. Manajemen Personalia dan Sumber Daya Manusia. Edisi

Kedua. Yogyakarta: BPFE.

Hasibuan Malayu S.P.(2009). Manajemen Sumber Daya Manusia. Edisi Revisi, Jakarta: PT. Bumi Aksara

Luthans, Fred. 1992. Organizational Behaviour. Sixth Edition. Singapore: McGraw- Hill, Inc.

Luthans, Fred. 1998. Organizational Behaviour. Eighth Edition. Singapore : McGraw- Hill Inc.

Mangkunegara, P. Anwar A.A. 2000. Manajemen Sumber Daya Manusia Perusahaan.

Bandung: PT Remaja Rosdakarya.

Martoyo, Susilo. 1996. Manajemen Sumber Daya Manusia. Edisi 3. Yogyakarta: BPFE. Mondy, Wayne and Robert M. Noe. 1993. Human Resources Management. Fifth 


\section{Peranan Career Anchor dalam Menciptakan Kepuasan,.. Moch. Wispandono}

Edition. Toronto: Allyn and Bacon.

Mondy R, Wayne, Rober M. Noe, \& Shane R., 2002.

Premeaux. Human Resource

Management, 8th Edition. Prentice Hall.

Nawawi, Hadari. 2008. Manajemen Sumber Daya Manusia. Gadjah Mada University

Press.

Nitisemito, Alex S. 1996. Manajemen Personalia. Jakarta: Ghalia Indonesia

Robbins, Stephen P. 1988. Management: Concept and Applications. Second Edition.

Englewood Cliffl, New Jersey: Prentice Hall International.

Robbins, Stephen P. 1996. Perilaku Organisasi : Konsep, Kontroversi, dan Aplikasi.

Jilid 2. Edisi Bahasa Indonesia. Terjemahan. Jakarta: PT Prenhallindo.

Rue, Leslie W and Lloyd L Byars. 1995. Management: Shlls and Application. Seventh

Edition. Illinois: Richard D. Irwin Inc.

Siagian, Sondang P. 1995. Teori Pengembangan Organisasi. Cetakan Pertama.

Bandung: Penerbit Bumi Aksara

Simamora, Henry. 1999. Manajemen Sumber Daya Manusia. Edisi Kedua. Yogyakarta: Bagian

Penerbitan Sekolah Tinggi Ilmu Ekonomi YKPN.

Singgih, Santoso. 2001. Buku Latihan SPSS Statistik Parametrik. Cetakan Kedua.

Jakarta: PT Elex Media Computindo.

Stoner, James A.F. 1994. Manajemen. Cetakan Keempat Jilid 1. Terjemahan. Jakarta: Penerbit Erlangga

Wexley, Kenneth N dan Gary A. Yulk. 1988. Perilaku Organisasi dan Psikologi.

Personalia. Terjemahan. Jakarta: Rineka Cipta

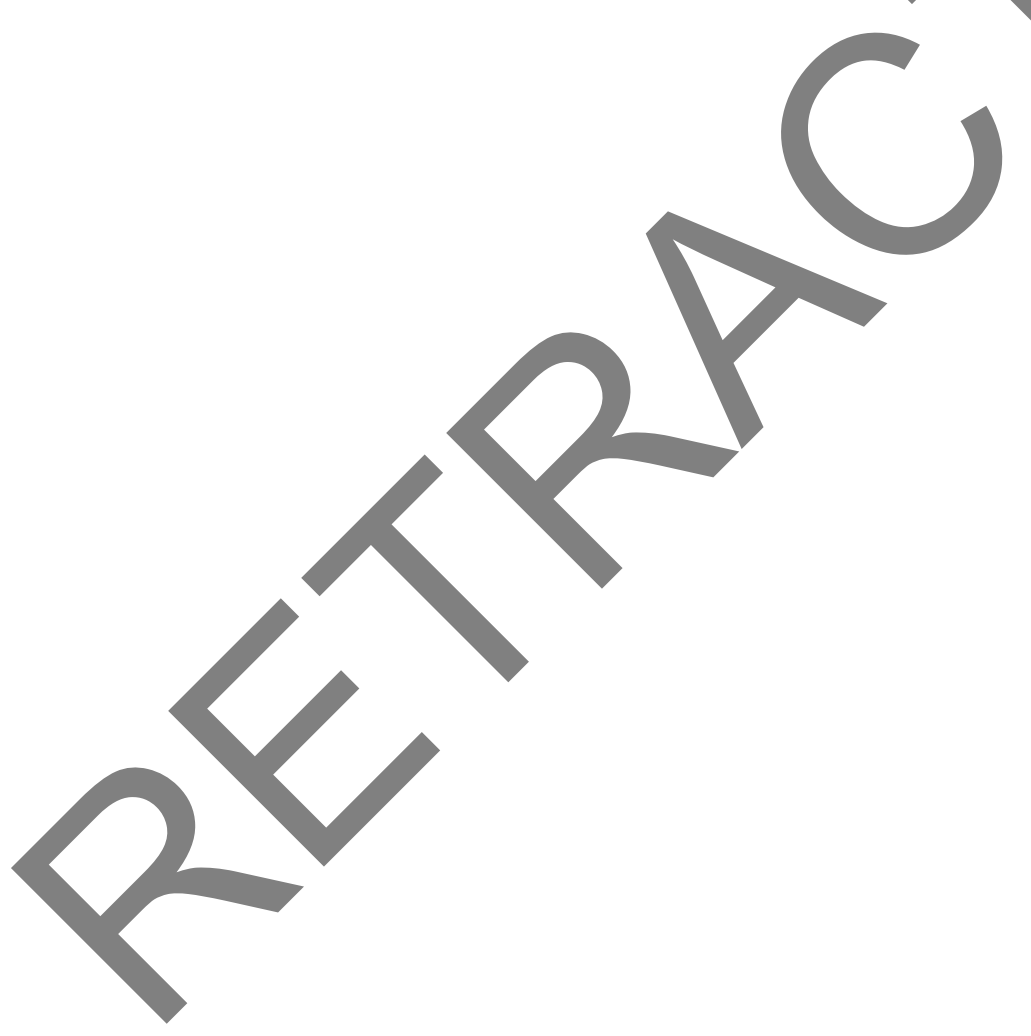

